\title{
Land-based predator impact on vertically migrating zooplankton and micronekton advected to a Southern Ocean archipelago
}

\author{
Renzo Perissinotto, Christopher D. McQuaid \\ Southern Ocean Group, Department of Zoology and Entomology, Rhodes University, PO Box 94, Grahamstown 6140 , \\ South Africa
}

\begin{abstract}
Combined acoustic (12 and $120 \mathrm{kHz}$ ) and trawling (RMT-2 and Bongo net) surveys in offshore waters of the Prince Edward Archipelago revealed diurnal vertical migration of major prey species (the euphausiid Euphausia vallentini and the myctophid fish Krefftichthys anderssoni) of landbased predators. Migration was from $200-400 \mathrm{~m}$ in the day to near-surface levels at night and was linked to feeding perodicity. Consistently high winds result in drift of surface waters (down to $10-20 \mathrm{~m}$ ) and advection of prey over the shelf Within the seasonal limits of the investigation (autumn), an estimated $3200 \mathrm{t}$ of zooplankton and $310 \mathrm{t}$ of myctophid fish were carried over the shelf every $24 \mathrm{~h}$. Predators in the archipelago consume ca $900 \mathrm{t}$ of crustaceans and $1700 \mathrm{t}$ of fish $\mathrm{d}^{-1}$ Thus, advection could supply sufficient crustaceans to the shelf area for the needs of the land-based predators, but is inadequate to support myctophid-feeding piscivores. Once over the shelf, prey attempting to migrate downwards would be trapped by bottom topography and vulnerable to predation. The fit between estimates of advection and consumption of different prey types is supported by observed prey densities and predator behaviour Prey density in shelf and oceanic waters was similar at night, but decreased dramatically over, and downstream of, the shelf in the day. Rockhopper and Macaroni penguins are the most important crustacean predators and feed mainly over the shelf, with foraging ranges of about 30 and $100 \mathrm{~km}$ respectively. In contrast, King penguins account for $>70 \%$ of the fish consumed in the area and forage in deep waters, having an average foraging range of $300 \mathrm{~km}$. This spatial segregation of the main predators is consistent with the availability of their prey.
\end{abstract}

\section{INTRODUCTION}

The distribution of marine food resources around islands in the Southern Ocean is of great interest because these areas support very large communities of land-based predators. Nowhere is the proportion of sea to land greater than in the Southern Ocean, where a vast oceanic region lies between 35 and $70^{\circ} \mathrm{S}$. This results in breeding localities being restricted to a fairly narrow latitudinal band where 23 small island groups are concentrated (mostly in the Atlantic and Indian sectors). Consequently, land-based predators have their greatest impact on food resources in these small, localized oceanic areas (Croxall 1984, Siegfried 1985).

The Prince Edward Archipelago $\left(47^{\circ} \mathrm{S}, 38^{\circ} \mathrm{E}\right)$ has breeding populations of 29 seabird and 3 seal species (Condy 1981, Cooper \& Berruti 1989), estimated at 4 to 6 million individuals (Williams et al. 1979, Cooper \&
Berruti 1989). The marine fish fauna of the archipelago also appears to be relatively rich, although it is still poorly known (Gon \& Klages 1988). These populations are obviously dependent on a prey-rich marine ecosystem, particularly the birds and seals which are engaged in energetically expensive activities such as breeding and moulting. Some fish and bottom-feeding seabirds (e.g. Gentoo penguin and Imperial cormorant) feed predominantly on the benthic shrimp Nauticaris marionis and on demersal fish (Espitalier-Noel et al. 1988, Adams \& Klages 1989, Perissinotto \& McQuaid 1990). However, the diet of most visual predators in the area is limited to pelagic organisms (Condy 1981, Adams 1987, Brown \& Klages 1987). Thus, assuming that the foraging range of these predators is mainly restricted to the circuminsular waters (Williams et al. 1979, Condy 1981, Adams 1987, Brown 1987, Adams \& Brown 1989), their feeding impact on the local zoo- 
plankton/nekton resources should be high and detectable on short time scales.

A preliminary study on the distribution of the zooplankton in the Prince Edward Island seas showed that there is a marked daytime decrease in biomass over the islands' shelf, compared to adjacent open ocean waters (Perissinotto 1989). Perissinotto (1989) suggested that this may be due to an interaction between zooplankton diurnal migrations and visual predators feeding in the shallow island seas. Here, this hypothesis is tested using the results of a combined hydroacoustic and net trawling survey carried out in the area during April/May and August 1989. Published data on the diet and feeding behaviour of various visual predators inhabiting the archipelago are used to estimate predator impact on the community of pelagic migrators.

\section{MATERIALS AND METHODS}

The acoustic survey was carried out aboard the SA 'Agulhas' during the second phase of the Marion Offshore Ecosystem Study (MOES-2) in April/May 1989 and during August 1989. An east-west (A-B) and a north-south $(\mathrm{C}-\mathrm{D})$ transect were occupied on both occasions (Fig. 1). Transects extended across the Prince Edward Plateau as far as the $1500 \mathrm{~m}$ depth contour, in open ocean waters. Along each transect, daytime (04:00 to 15:00 h GMT) and nighttime (16:00 to 03:00 h GMT) crossings were recorded on echograms at a ship speed of 6 to 10 knots. The distribution of zooplankton (euphausiids) and mesopelagic fish scatterers was monitored continuously by echo-sounders operated at 2 different frequencies (Falk-Petersen \& Hopkins 1981, Orr 1981, Greenlaw \& Pearcy 1985). A Simrad EKS was operated at $120 \mathrm{kHz}$ (maximum penetration depth ca $200 \mathrm{~m}$ ) while a NEC NS-74 DeepSea system was operated at a resonance frequency of $12 \mathrm{kHz}$ (maximum penetration depth ca $6000 \mathrm{~m}$ ). During April/May 1989, the acoustic survey along Transect $\mathrm{A}-\mathrm{B}$ was combined with zooplankton and micronekton target identification. Samples were collected using an opening-closing RMT-2 net $(4 \mathrm{~mm}$ mesh, darkened) controlled by a Universal Underwater Unit (Robertson et al. 1981), towed at 2.5 to 3.0 knots. Surface, midwater and bottom/deep hauls were made on the shallowest (Natal Bank) and oceanic (Stn B) parts of the transect, both during the morning and at night. In addition, two $24 \mathrm{~h}$ stations (Fig. 1) were occupied at the end of the acoustic survey to compare diurnal variations in zooplankton biomass on the islands' shelf ( $\operatorname{Stn} \mathrm{E}$ ) with those in deep waters (Stn F). Oblique hauls were made to the surtace from the bottom (shelf) or from between 300 and $400 \mathrm{~m}$ (open ocean), at $3 \mathrm{~h}$ intervals with a $60 \mathrm{~cm}$ mouth Bongo net, $300 \mu \mathrm{m}$ mesh. Net operations were again monitored with a Universal Underwater Unit. Another 18 Bongo tows, from $300 \mathrm{~m}$ to the surface, were made from an extensive grid of stations around the archipelago (Fig. 2).

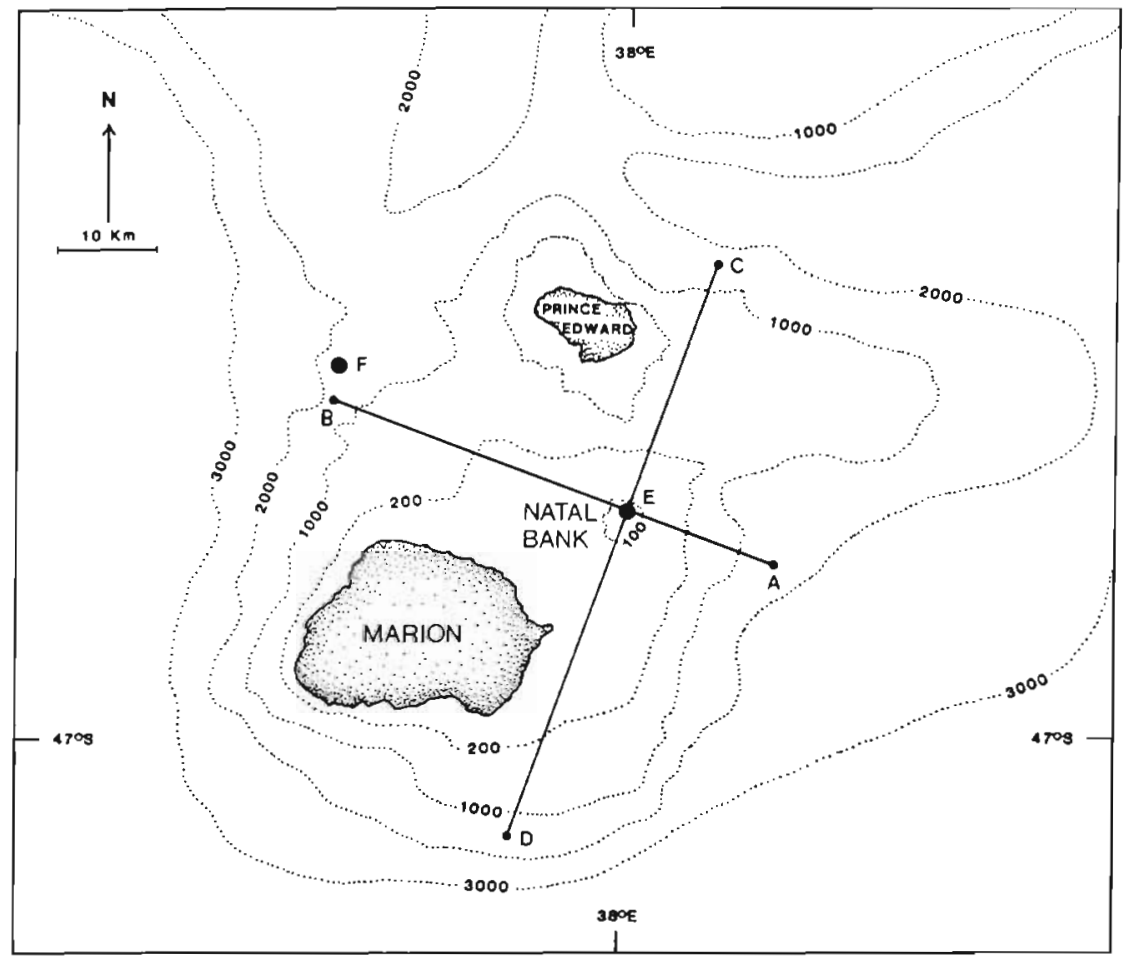

Fig. 1. The 2 transects ( $A-B$ and $C-D$ ) of the combined acoustic and RMT-2 trawling survey. Positions $E$ and $F$ represent the $24 \mathrm{~h}$ stations of the Bongo net sampling; isobaths given in $\mathrm{m}$ 
Fig. 2. Bottom topography (isobaths in $\mathrm{m}$ ) and cruise track along the extensive grid of stations ( $)$ occupied in April/May 1989

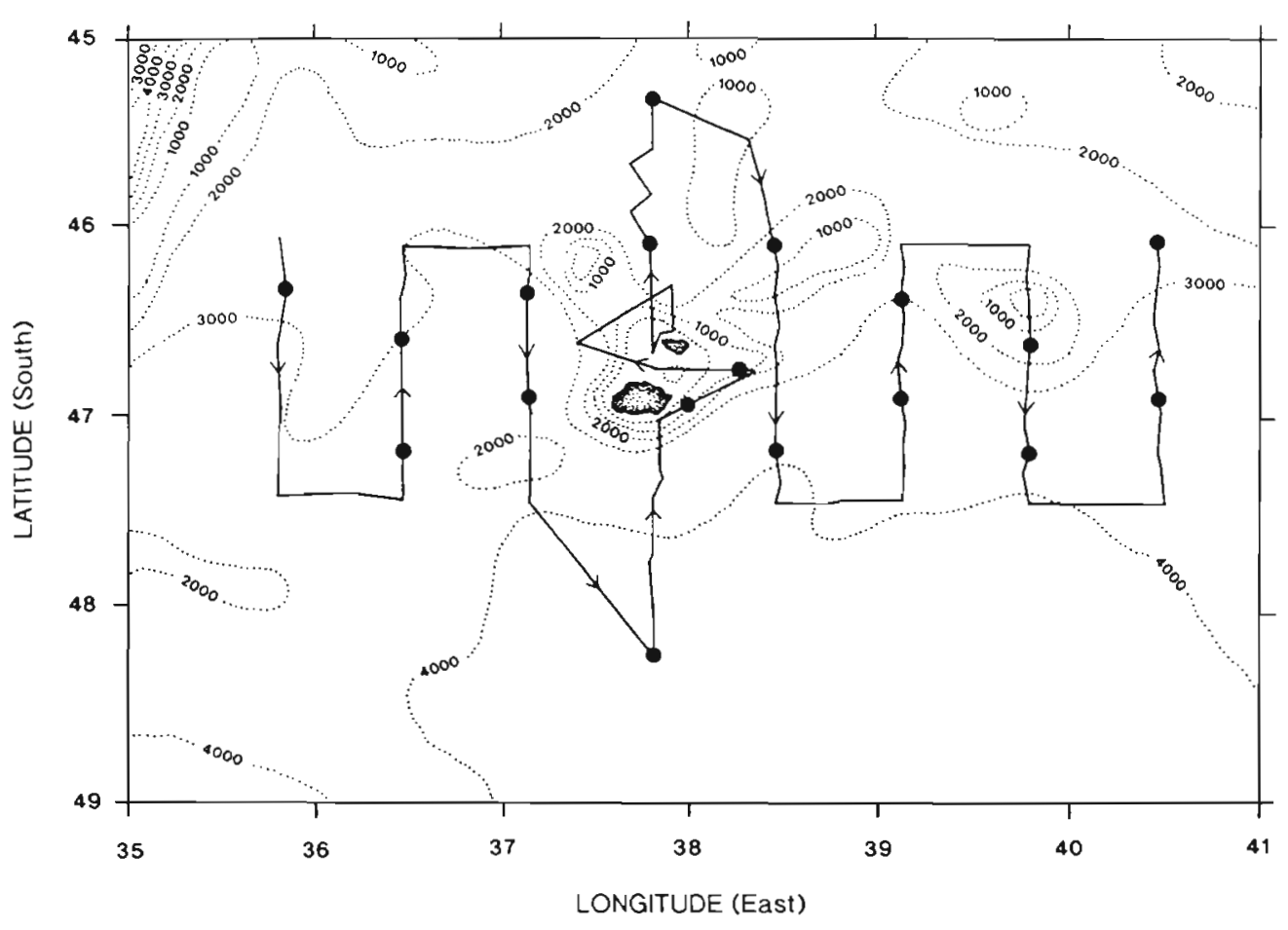

Zooplankton and micronekton samples were preserved in $5 \%$ buffered formalin. Abundance estimates were obtained by counting entire RMT-2 samples and aliquots of $20 \%$ of the original samples collected with the Bongo net. A Wiborg's modified whirling apparatus (Kott 1953) was used to obtain the subsamples. Zooplankton biomass was determined by removing solution and interstitial liquids with the vacuum extraction technique (Beers 1976) and expressed as displacement volume of each sample. The wet weight (WW) of fish was calculated from measurements of each individual from the micronekton samples collected with RMT-2 nets.

Stomach content analysis was performed on notothenioid and myctophid fish collected by RMT-2 trawling. Altogether, 66 fish stomachs were removed and their prey contents identified and counted under a dissecting microscope at $250 \times$ magnification.

\section{RESULTS}

\section{Acoustic survey}

Daytime $12 \mathrm{kHz}$ acoustic records showed a deepscattering layer (DSL) at 300 to $400 \mathrm{~m}$ depth (Figs. 3 $\& 4$ ). Typically, the scatterer was very strong in deep water areas and faded gradually towards the islands' shelf (Fig. 4A). The layer started to rise at dusk (ca 15:00 h GMT), reaching 150 to $200 \mathrm{~m}$ within $1 \mathrm{~h}$ (Fig. 3). During the night this scatterer was recorded only in the upper $100 \mathrm{~m}$ of the water column (Fig. 4B). At dawn (04:00 h GMT) the layer reappeared at a depth of $150 \mathrm{~m}$ and then sank to its daytime level (300 to $400 \mathrm{~m}$ ). In the shelf area discrete $12 \mathrm{kHz}$ scatterers were occasionally seen during both day and night but showed high intensities only in the early morning (03:00 to 05:00 h GMT; Fig. 5). Dawn patches of strong scatterers were observed throughout the shelf area but not in offshore waters. These patches formed vertically elongated plumes from the shelf bottom, some extending up to $50 \mathrm{~m}$ above the sea bed (Fig. 5).

Two high-frequency ( $120 \mathrm{kHz})$ backscattering layers were recorded. A thin (ca $5 \mathrm{~m}$ ) suprabenthic layer (BSL) was recorded 5 to $10 \mathrm{~m}$ above the shelf bottom during both day and night (Fig. 6). At dusk, a surface scatterer (SSL) 20 to $50 \mathrm{~m}$ thick also appeared both over the shelf and in oceanic waters (Fig. 6B). The SSL became less dense and sank during the night, dissipating completely in the early morning. Maximum depth penetration of the Simrad echo-sounder was $200 \mathrm{~m}$ and no scatterers in oceanic waters were recorded to this depth during the day.

\section{Trawling survey}

RMT-2 catches showed that the only large daytime resonance-frequency target present in the oceanic DSL was the myctophid fish Krefftichthys anderssoni (Table 1). Fish density in the 300 to $400 \mathrm{~m}$ DSL was 


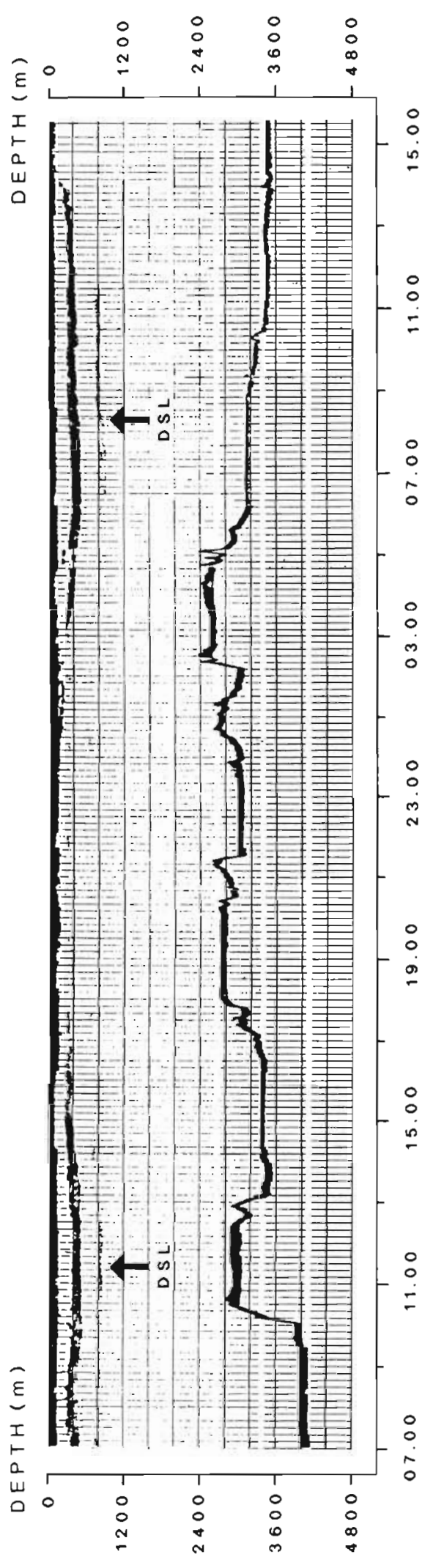

12.2 ind. $1000 \mathrm{~m}^{-3}$. All $K$. anderssoni captured at this depth were juveniles or sub-adults of standard length (SL) 22 to $52 \mathrm{~mm}$, with a size-frequency mode evenly distributed in the range 23 to $48 \mathrm{~mm}$. Other mesopelagic fish species were found only in night trawls, in the upper $150 \mathrm{~m}$, and in small numbers. These were the myctophids Protomyctophum andriashevi, Electrona antarctica and Gymnoscopelus bolini. The notothenioid Lepidonotothen larseni was found only on the shelf area (day and night) in near-bottom trawls. Maximum densities were about 7 L. larseni $1000 \mathrm{~m}^{-3}$ (Table 1).

The $120 \mathrm{kHz}$ BSL on the shelf bottom (140 m) was dominated by the caridean shrimp Nauticaris marionis (55 to 91 ind. $100 \mathrm{~m}^{-3}$ ) and the chaetognath Sagitta sp. (Table 1). Vertical migrators were found in high concentrations at 300 to $400 \mathrm{~m}$ in oceanic waters during the day (e.g. Euphausia vallentini, 165 ind. $100 \mathrm{~m}^{-3}$ ), but only in very low numbers on the shelf bottom. Nighttime trawls showed that migration of E. vallentini to the surface was responsible for the appearance of the nocturnal SSL recorded at $120 \mathrm{kHz}$ both over the shelf and in deep waters (Table 1 and Fig. 6B). All E. vallentini collected were in the post-furcilial, subadult or adult stage and the total body length (BL) varied from 10 to $26 \mathrm{~mm}$, with a mode in the size-frequency distribution between 17.1 and $23.2 \mathrm{~mm}$. The large copepod Rhincalanus gigas also occurred in the surface layer only at night. Its daylight depth was considerably shallower (ca 150 to $200 \mathrm{~m}$ ) than that of $E$. vallentini (Table 1).

High temporal resolution Bongo tows confirmed this pattern. Zooplankton biomass levels (displacement volume $\mathrm{m}^{-3}$ ) on the shelf and in oceanic waters were very similar at night $\left(0.131\right.$ and $0.143 \mathrm{ml} \mathrm{m}^{-3}$, respectively), but were significantly different ( $t$-test, $p<0.001$ ) during the day (Fig. 7). On Natal Bank (Stn E, Fig. 1), zooplankton biomass dropped dramatically in the early morning (04:00 to 06:00 h GMT) and remained very low (mean $0.063 \mathrm{ml} \mathrm{m}^{-3}$ ) throughout the day. This decrease was almost exclusively due to the disappearance of Euphausia vallentini and Rhincalanus gigas. Biomass rose to nighttime levels again around dusk (14:00 to $16: 00 \mathrm{~h}$ GMT). In contrast, at the oceanic station (Stn F, Fig. 1) daytime zooplankton biomass decreased only to $0.117 \mathrm{ml} \mathrm{m}^{-3}$ and was not significantly different ( $t$-test, $p>0.05$ ) from nighttime levels (Fig. 7).

The grid of stations around the archipelago also showed a distinct reduction in zooplankton biomass over and downstream of the plateau. While high levels $\left(0.20\right.$ to $\left.0.30 \mathrm{ml} \mathrm{m} \mathrm{m}^{-3}\right)$ were found to the east and west of the archipelago, the islands' shelf and the shoaling ridge on its downstream side usually had $<0.10 \mathrm{ml} \mathrm{m}^{-3}$ (Fig. 8) 


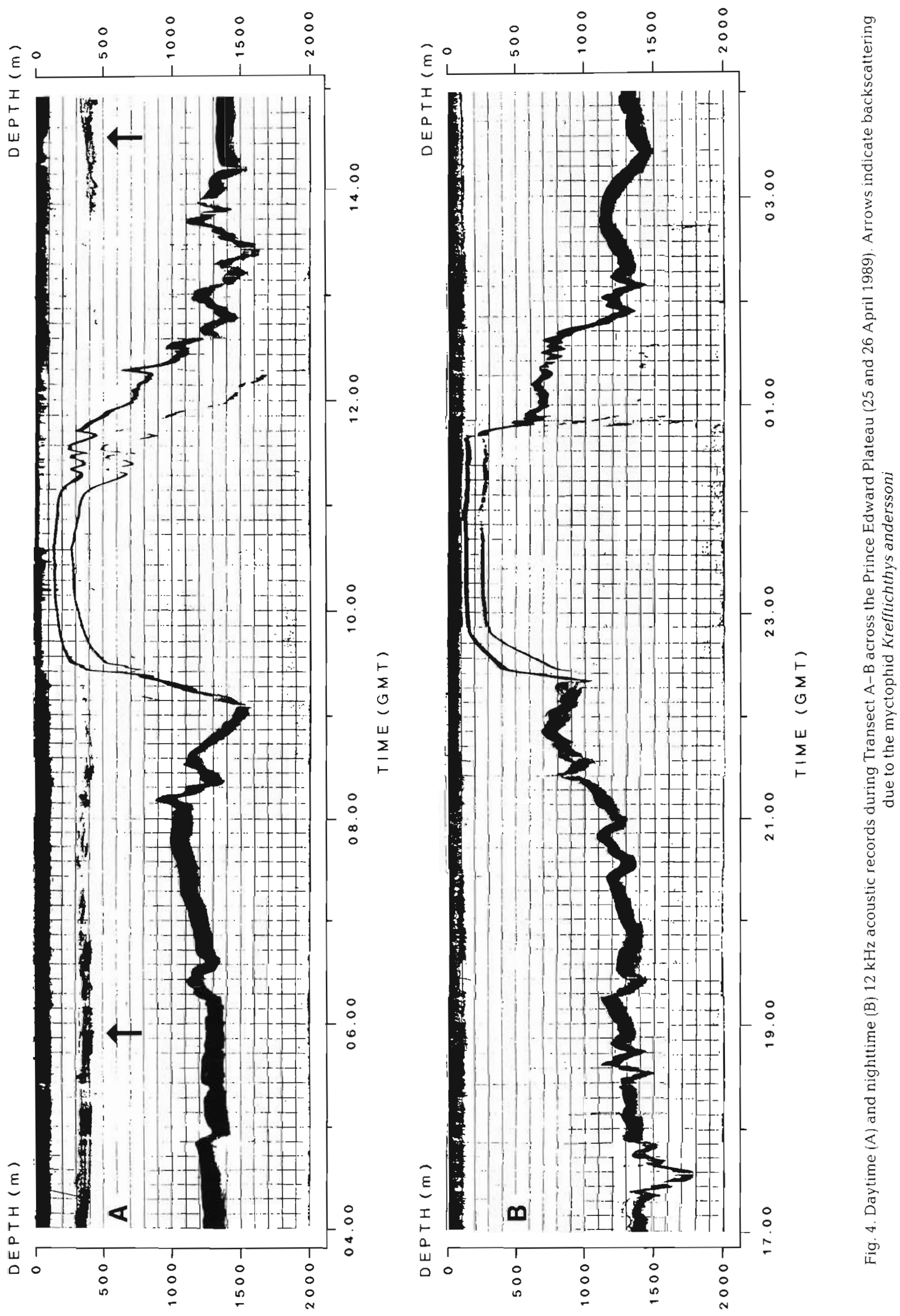




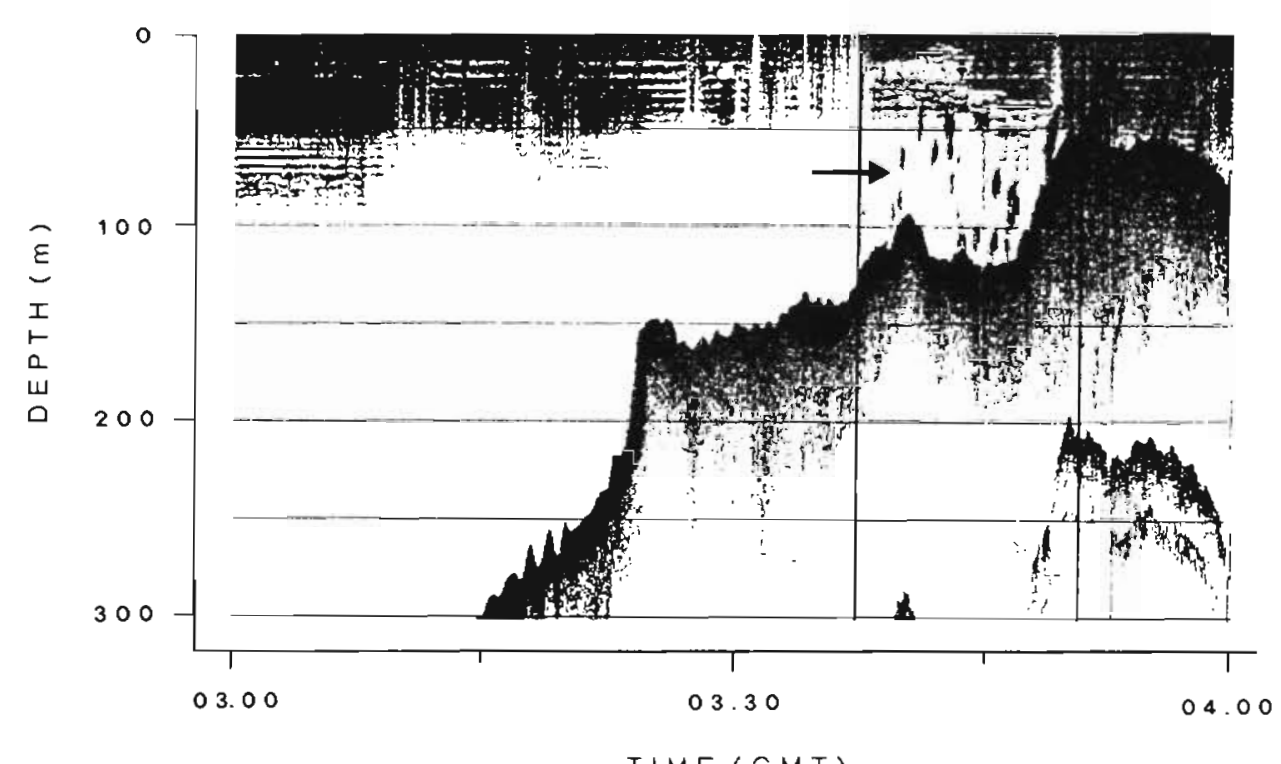

Fig. 5. $12 \mathrm{kHz}$ acoustic record taken at dawn in the shelf area of the Prince Edward Archipelago (26 August 1989). Arrow indicates discrete scatterers rising from the bottom
Analysis of fish stomach contents showed that copepods and ostracods were the dominant prey items of all fish species captured (Table 2). The myctophid Kreffrichthys anderssoni ate mainly Microcalanus pygmaeus $(49 \%)$ and Oithona spp. (23\%), while the neritic notothenioid Lepidonotethen larseni fed mainly on Calanus simillimus (35\%) and Metridia gerlachei (31\%). Euphausiid prey were almost exclusively calyptopis and furcilia stages of Euphausia vallentini. They formed only 3.2 and $12 \%$ of gut contents by number for $K$. anderssoni and $L$. larseni respectively, but ofter contributed more by mass than copepods (mean 33 and $52 \%$ ). Other prey taxa occurred in very low numbers and included the chaetognath Sagitta sp., larval hyperiid amphipods and benthic tanaid isopods and amphipods.

Kreffrichthys anderssoni exhibited diurnal feeding periodicity (Table 2). Stomachs of $K$.anderssoni taken at night contained significantly more prey items than those taken during the day at 300 to $400 \mathrm{~m}$ (mean 34.8 \pm 16.8 and $8.9 \pm 6.4$ prey fish $^{-1}$, respectively). No diel differences were observed in the gut fullness of Lepidonotothen larseni which appeared to feed continuously (Table 2).

\section{DISCUSSION}

\section{Prey availability}

A special effort has been made during the past decade to resolve the feeding ecology and the metabolic requirements of the land-based predators of the Prince Edward Archipelago. For the season during which the investigation took place, data in the literature estimate their total food consumption to be 1700,900 and $800 \mathrm{t}$ (wet weight) $\mathrm{d}^{-1}$ of fish, crustaceans and squid, respectively (Table 3 ).

Penguins and seals represent over $90 \%$ of the total biomass of the land-based predators (Condy 1981, Adams \& Brown 1989, Adams 1990). With the exception of Gentoo penguins, which feed extensively on benthic prey, particularly the shrimp Nauticaris marionis (Adams \& Klages 1987, 1989, Brown \& Klages 1987, Perissinotto \& McQuaid 1990), all these predators are pursuit divers feeding primarily on epi- and mesopelagic prey (Croxall 1984, Croxall et al. 1985, Fraser et al. 1989). Pelagic prey densities around the islands are often low and it has been suggested that much of the predator population is supported by continuous input of allochthonous pelagic prey advected over the islands' shelf (Brown 1989, Perissinotto 1989).

The results of the survey show that the myctophid Krefftichthys anderssoni, the euphausiid Euphausia vallentini and the copepod Rhincalanus gigas undergo diurnal vertical migration. E. vallentini and several copepod species have cyclic feeding habits (Perissinotto \& Boden 1989, Perissinotto 1992), and at night all crustacean migrators were most abundant in the surface tows (Table 1) forming a dense SSL in the top 20 to $50 \mathrm{~m}$ of the water column at dusk (Fig. 6B).

The mesopelagic fish Kreffrichthys anderssoni formed a distinct DSL just below the crustaceans at 300 to $400 \mathrm{~m}$ during the day, shifting to the upper 50 to $100 \mathrm{~m}$ at night (Fig 3). It is evident from stomach contents that this migration is, in turn, related to nighttime feeding on crustacean prey (especially Euphausia vallentini and Microcalanus pygmaeus) in surface waters (Table 2). 


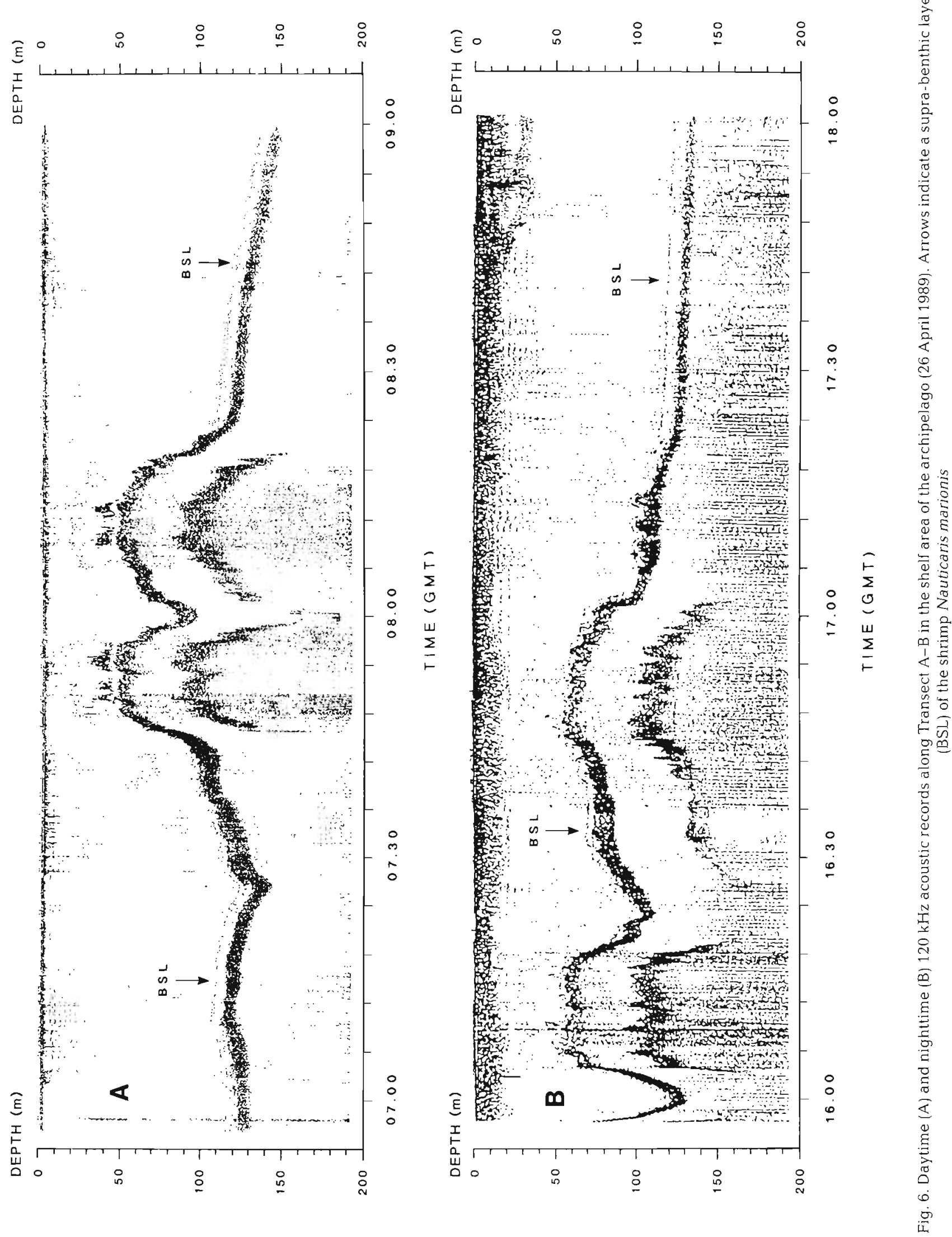


Table 1. Concentrations of the major macrozooplankton taxa (ind. $100 \mathrm{~m}^{-3}$ ) and micronekton (ind. $1000 \mathrm{~m}^{-3}$ ) on the islands' shelf and offshore of the Prince Edward Archipelago. Samples were collected on 26 April 1989 by horizontal hauls with openingclosing RMT-2 nets. Sur.: surface; Mid.: midwater; Bot.: bottom

\begin{tabular}{|c|c|c|c|c|c|c|c|c|c|c|c|c|}
\hline \multirow[t]{2}{*}{ Taxon } & \multicolumn{3}{|c|}{ Day, Natal Bank } & \multicolumn{3}{|c|}{ Night, Natal Bank } & \multicolumn{3}{|c|}{ Day, offshore } & \multicolumn{3}{|c|}{ Night, offshore } \\
\hline & $\begin{array}{l}\text { Sur. } \\
10 \mathrm{~m}\end{array}$ & $\begin{array}{l}\text { Mid. } \\
70 \mathrm{~m}\end{array}$ & $\begin{array}{l}\text { Bot. } \\
140 \mathrm{~m}\end{array}$ & $\begin{array}{l}\text { Sur. } \\
10 \mathrm{~m}\end{array}$ & $\begin{array}{l}\text { Mid. } \\
70 \mathrm{~m}\end{array}$ & $\begin{array}{c}\text { Bot. } \\
140 \mathrm{~m}\end{array}$ & $\begin{array}{l}\text { Sur. } \\
10 \mathrm{~m}\end{array}$ & $\begin{array}{l}\text { Mid. } \\
150 \mathrm{~m}\end{array}$ & $\begin{array}{l}\text { Deep } \\
400 \mathrm{~m}\end{array}$ & $\begin{array}{l}\text { Sur. } \\
10 \mathrm{~m}\end{array}$ & $\begin{array}{l}\text { Mid. } \\
150 \mathrm{~m}\end{array}$ & $\begin{array}{l}\text { Deep } \\
400 \mathrm{~m}\end{array}$ \\
\hline Rhincalanus gigas & - & - & 2.1 & 6.3 & 13.6 & 0.8 & - & 7.8 & - & 9.2 & 2.3 & - \\
\hline Euphausia vallentini & - & - & 2.6 & 92.8 & 31.8 & 5.1 & 3.3 & 10.9 & 165.3 & 139.9 & 86.4 & 12.6 \\
\hline Themisto gaudichaudii & 0.7 & 2.9 & 1.5 & 0.7 & 8.1 & 5.1 & 9.9 & 9.1 & - & 1.6 & 9.1 & 0.6 \\
\hline Nauticaris manionis & - & 6.2 & 91.0 & 11.0 & 63.6 & 55.1 & - & - & - & - & - & - \\
\hline Conchoecia sp. & - & 3.8 & 7.7 & 4.8 & 1.3 & 3.2 & 0.4 & 1.7 & - & 3.2 & 9.1 & - \\
\hline Sagitta sp. & 51.5 & 34.4 & 25.1 & 18.8 & 106.3 & 85.9 & 19.0 & 31.8 & 35.0 & 32.9 & 94.1 & 61.4 \\
\hline Salpa fusiformis & - & 3.3 & 5.6 & 1.1 & - & 5.9 & 9.1 & 14.8 & - & 3.9 & 15.9 & 0.6 \\
\hline Lepidonotothen larseni & - & - & 3.6 & - & - & 7.3 & - & - & - & - & - & - \\
\hline Krefftichtys anderssoni & - & 1.4 & 0.6 & - & 5.4 & 3.5 & - & - & 12.2 & 0.8 & 7.9 & 1.3 \\
\hline
\end{tabular}

Migration of crustaceans and mesopelagic fish to the surface layers exposes them to rapid advection. Around the archipelago, the eastward-flowing Antarctic Circumpolalar Current is enhanced at the surface by local wind stress effects. The strong, predominantly northwesterly winds that blow in this area at an average speed of $10 \mathrm{~m} \mathrm{~s}^{-1}$ (Smith 1987, South African Weather Bureau pers. comm.) can generate an

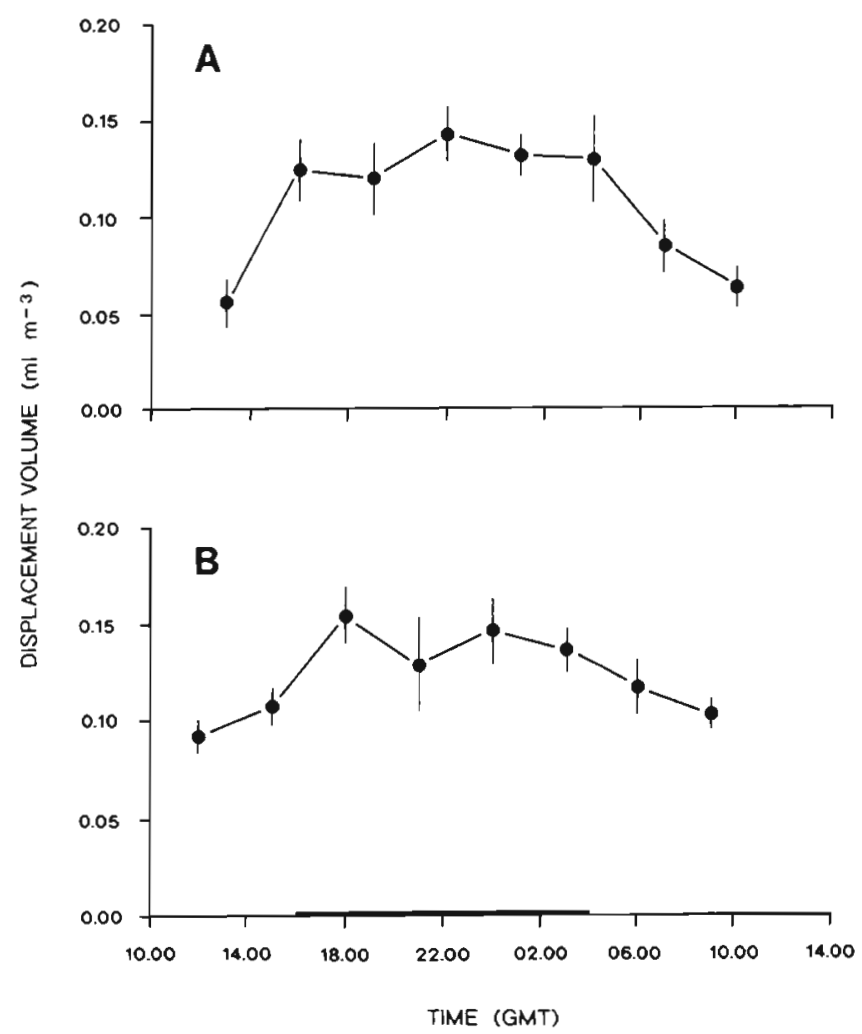

Fig. 7 Total zooplankton biomass in the shelf area (A) and oceanic waters (B) of the Prince Edward Archipelago during May 1989 . Heavy horizontal bar: nighttime average wind-driven Ekman drift of about $30 \mathrm{~cm} \mathrm{~s}^{-1}$ (Perissinotto 1989). This drift is substantial only in a very thin layer of the upper water column (10 to $20 \mathrm{~m})$, since the Ekman velocity falls off exponentially with depth. The time required for a surface front of pelagic organisms to be advected across the islands' shelt would be less than $12 \mathrm{~h}$. Shelf waters could then be supplied with a steady flux of pelagic migrators during nighttime, when these are located at near-surface depths (Perissinotto 1989).

Given that the upstream (west) edge of the islands' plateau is ca $40 \mathrm{~km}$ long, with strong drift in the upper $20 \mathrm{~m}$, a vertical section ( $S$ ) of ca $8 \times 10^{5} \mathrm{~m}^{2}$ of the upper mixed layer is exposed to surface Ekman drift. The total flux of zooplankton and mesopelagic fish into the shelf area during a night period of $12 \mathrm{~h}$ can be estimated given an advection speed $\left(u\right.$ ) of ca $0.3 \mathrm{~m} \mathrm{~s}^{-1}$ and an average zooplankton concentration $\left(C_{z}\right)$ of about $40 \mathrm{mg}$ dry wt (DW) $\mathrm{m}^{-3}$ upstream of the archipelago (Perissinotto 1989). Total flux would be:

$$
\begin{aligned}
S \times u \times C_{2} \times 12 & \approx 8 \times 10^{5} \times 0.3 \times 40 \times 4.32 \times 10^{4} \\
& \approx 415 \mathrm{t} \mathrm{DW} \mathrm{d}^{-1}
\end{aligned}
$$

This can be converted into wet weight (WW) biomass units using the regression equation suggested by Wiebe et al. (1975):

$$
\log (W W)=-1.983+0.922 \log (D W)
$$

where WW is expressed in $\mathrm{g} \mathrm{m}^{-3}$ and DW in $\mathrm{mg} \mathrm{m}^{-3} \cdot \mathrm{A}$ biomass of $415 \mathrm{t} \mathrm{DW} \mathrm{d}^{-1}$ yields ca $3200 \mathrm{t} \mathrm{WW} \mathrm{d}^{-1}$.

The biomass of myctophids in the surface layer in open waters was ca $30 \mathrm{mg} \mathrm{WW} \mathrm{m}^{-3}$. Calculated as for zooplankton advection, this gives a total daily influx of ca $310 \mathrm{t} W \mathrm{~W}$ of myctophids over the shelf.

Unlike most surface-feeding predators, which feed only at night when vertical migrators rise to the surface 
Fig. 8. Zooplankton displacement volume (ml $\mathrm{m}^{-3}$ ) within the extensive grid of stations $(\bullet)$ occupied in April/May 1989

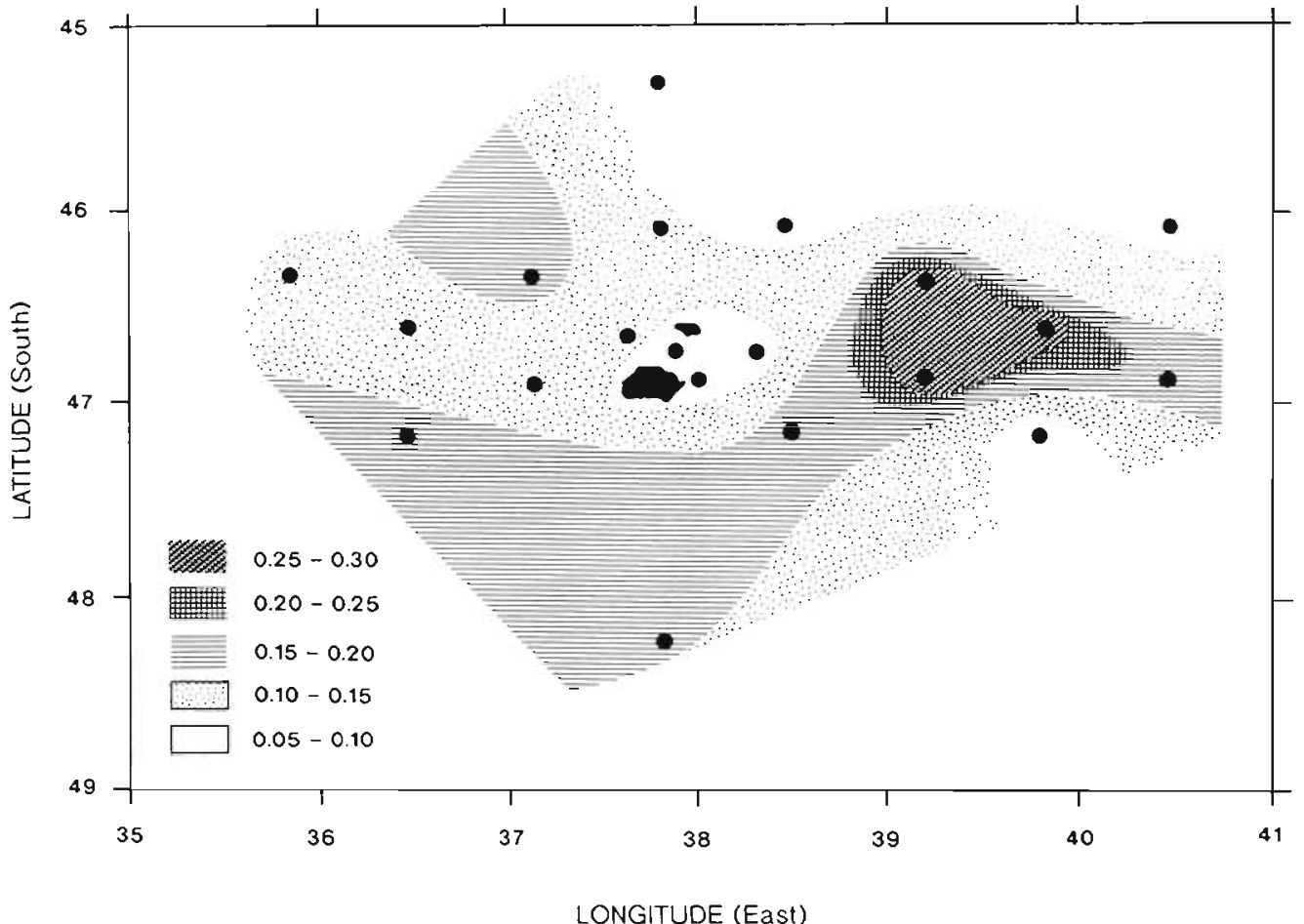

(Imber 1973), diving species such as seals and penguins are most active during daytime (Croxall et al. 1988, Wilson \& Wilson 1990). Vertical migrators, advected over the shelf during the night, are therefore likely to be exposed to heavy predation from the first hours of daylight, when they begin their descent to deep waters. As the shelf is shallower than the usual daytime residence depth of these migrators, their diurnal descent would be limited by the bottom topography. Migrators would then be concentrated at or near the bottom, where they become available to diving predators. The presence of Nauticaris marionis in penguin guts implies that they are able to dive to the shelf bottom (50 to $200 \mathrm{~m}$ ) and feed on migrators trapped at these depths (Adams \& Klages 1987, 1989, Brown \& Klages 1987, Perissinotto \& McQuaid 1990).

\section{Predator impact}

If diurnal predation on migrating crustaceans and fish is sufficiently intense, it should create patches devoid of migrators and decrease their overall abundance in the vicinity of the shoaling plateau. This was bornc out in the surveys.

Nocturnal concentrations of zooplankton were similar over the shelf and in open waters, but migrating crustaceans virtually disappeared from the shelf during daylight (Fig. 7). While RMT-2 catches in the supra-benthic layer showed high concentrations of the benthic shrimp Nauticaris marionis, densities of Euphausia vallentini and Rhincalanus gigas were extremely low (Table 1). The same pattern was observed for the mesopelagic Kreffrichthys anderssoni with a single suggestive exception. Kelp beds offer some protection from visual predators and relatively high daytime concentrations of $K$. anderssoni occurred in the kelp bed on Natal Bank, the shallowest part of the shelf (Table 1).

Within a time scale longer than the advective time, the community of vertical migrators downstream of the plateau should also be depleted as a result of predation over the islands' shelf. The zone of reduced zooplankton biomass, observed within the extensive grid of stations occupied in April/May 1989, seems to support this hypothesis. On that occasion, the area of biomass depletion extended to about $20 \mathrm{~km}$ downstream of the shelf (Fig. 8).

In spite of complex seasonal and annual variations in the foraging parameters of the main predators, there is some circumstantial evidence of covariance between the composition of their diets and prey availability and abundance around the archipelago (Adams 1990, Brown et al. 1990). In austral fall, the major piscivores, King and Macaroni penguins consume predominantly Kreffrichthys anderssoni. The size-frequency distribution of this myctophid in the diet of King penguins is bimodal, with peaks at 25.2 and $47.5 \mathrm{~mm} \mathrm{SL}$, and has a single modal peak at ca $35 \mathrm{~mm}$ in Macaroni penguins (Adams \& Klages 1987, Brown \& Klages 1987). These 


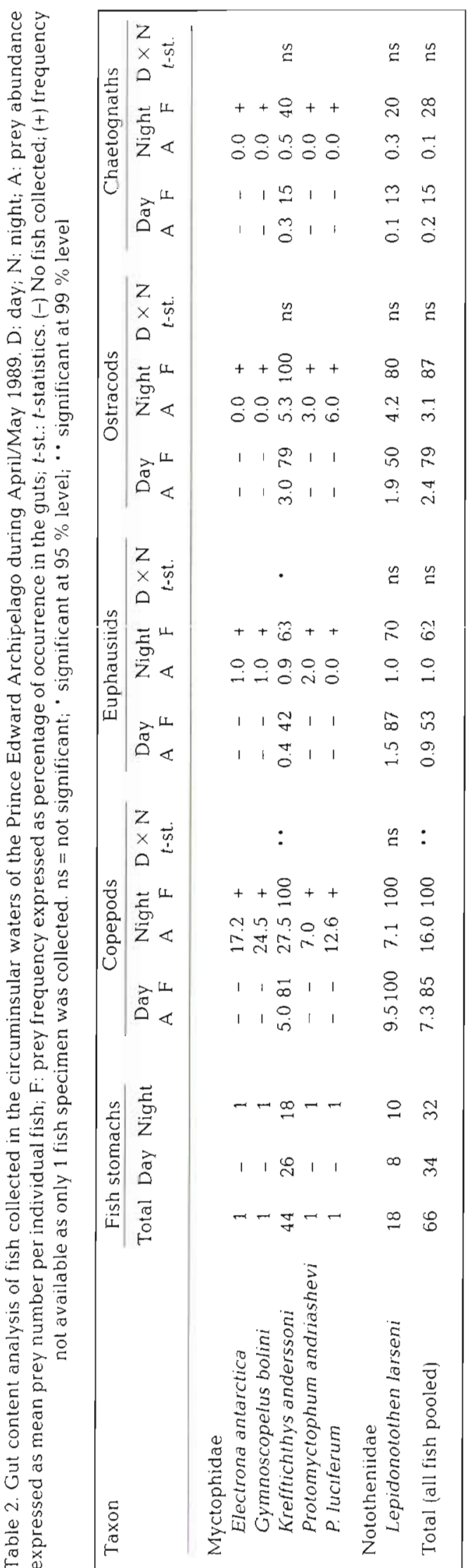

values overlap entirely with the modal range of 23 to $48 \mathrm{~mm}$ for $K$. anderssoni collected during the RMT-2 trawling survey. Similarly, Euphausia vallentini, one of the major prey items of Macaroni and Rockhopper penguins, exhibits in their diets a mode in the range 18 to $23 \mathrm{~mm} \mathrm{BL}$ (Brown \& Klages 1987) that matches its size-frequency distribution in the net catches (modal range 17.1 to $23.2 \mathrm{~mm}$ ).

It seems reasonable, therefore, to assume that the observed decrease in prey biomass on the islands' shelf is the direct result of the foraging activities of these predators.

The daytime decrease in biomass on the shelf, relative to the deep waters, is about $35 \%$ of the total zooplankton (almost exclusively due to migrating crustaceans) and over $80 \%$ of the fish advected during the night (Fig. 7 and Table 1; Perissinotto 1989). Assuming that this decrease was entirely due to local predation during the day, then an average of ca $1100 \mathrm{t} W W$ of crustaceans and of ca $250 \mathrm{t}$ of fish would be consumed per day in the shelf area. When these estimates are compared to the daily food requirements of the landbased predators (Table 3), it is found that depletion of crustaceans advected over the shelf exceeds predation rates by $200 \mathrm{t}$, while the supply of fish accounts for only $15 \%$ of predator consumption.

The excess of crustaceans apparently consumed over the shelf during daytime may be accounted for by the endemic fish community (Blankley 1982, Gon \& Klages 1988). At least 10 species of notothenioids have been found in the Prince Edward Islands and 2 of these, Paranotothenia magellanica and Lepidonotothen larseni, are particularly abundant in the shelf area (Table 1 ; Gon \& Klages 1988). Notothenioids are considered to be bottom-dwelling fish but many are adapted for temporary or permanent pelagic life and feed primarily on planktonic crustaceans in the mid-water zone (Targett 1981, Duhamel \& Hureau 1985, De Witt et al. 1990).

Targett (1981) has suggested an average daily wet weight ration for such fish of $0.87 \%$ of body weight. In this case the excess supply of crustaceans could support a notothenioid population of at least $2.3 \times 10^{4} \mathrm{t}$. This is equivalent to ca $3 \%$ of the biomass of the community of land-based predators.

There is also evidence that a significant population of other benthic fish inhabits the archipelago. Notothenioids lack swim bladders and so cannot be detected in the water column with resonant-frequency acoustic methods (Eastman 1985, 1990). Thus, they cannot account for the strong, discrete $12 \mathrm{kHz}$ scatterers observed over the shelf (Fig. 6). These scatterers were usually observed in the early morning hours (03:00 to 05:00 h GMT) and formed plumes extending 
Table 3. Daily food consumption (t wet wt) of the main land-based predators at the Prince Edward Archipelago. For penguins only, figures are based on seasonal consumption for the period of the investigation. All other values were calculated from estimates of annual food requirements given by the various sources

\begin{tabular}{|lccccc|}
\hline Predator & Fish & Crustaceans & Squid & Total & Source \\
\hline King penguin Aptenodytes patagonicus & 1599 & Trace & 177 & 1776 \\
Macaroni penguin Eudyptes chrysolophus & 82.7 & 331 & 95.3 & 509 \\
Rockhopper penguin Eudyptes chrysocome & 8.52 & 113 & 2.56 & 124 & \\
Gentoo penguin Pygoscelis papua & 1.94 & 2.11 & 0.08 & 4.13 & Adams (1990) \\
Penguins, Family Spheniscidae (total) & 1692 & 446 & 275 & 2413 & Condy (1981) \\
Seals, Order Pinnipedia & 27.1 & 1.07 & 66.8 & 94.9 & Brown (1989) \\
Petrels \& prions, Family Procellariidae & 150 & 167 & 74.2 & 391 & Adams et al. (1986) \\
Wandering albatross Diomedea exulans & 0.47 & 0.47 & 3.70 & 4.64 & \\
Total & 1870 & 614 & 420 & 2904 & \\
\hline
\end{tabular}

up to $50 \mathrm{~m}$ above the shelf bed. Although the scatterers were not sampled with the RMT-2 net, it is likely that they represent demersal fish rising from the bottom to feed on the vertical migrators that are descending to their daylight depths. This is a common feature of predator-prey relationships occurring over shoaling topography bathed by directional flows (Isaacs \& Schwartzlose 1965, Peryera et al. 1969, Genin et al. 1988).

\section{Predator ecology}

Differences in the availability of fish and crustacean prey within the shelf area may play a major role in the spatial segregation of co-occurring predators with different foraging behaviours.

Given the poor supply of mesopelagic fish over the shelf area, piscivorous predators would be able to meet their daily food requirements only by travelling further afield, into deep oceanic areas. For example, dense aggregations of Kreffrichthys anderssoni were found only in open ocean waters, well off the shelf (Fig. 4A). King penguins feed on fish and account for ca $75 \%$ of the mesopelagic fish consumed by the local predators (Table 3 ). They have a mean maximum foraging range of ca $300 \mathrm{~km}$ and undertake long feeding excursions (>3 d) to the deep waters surrounding the archipelago (Adams 1987, Adams \& Brown 1989). During the day $K$. anderssoni was concentrated between 300 and 400 $m$ (Figs. $3 \& 4$ ). Although half of the feeding dives of the King penguin exceed $50 \mathrm{~m}$, it rarely dives below $240 \mathrm{~m}$ (Kooyman et al. 1982) and so is unlikely to feed during the day. Penguins may locate prey in the dark by detecting the natural bioluminescence of certain fish and squid (Croxall \& Lishman 1987) and feeding could occur at night, when the mesopelagic fish and squid occur near the surface. It seems more likely, however, that penguins feed at dusk and dawn when prey are both visible and abundant near the surface, as does the Antarctic Fur seal (Croxall et al. 1985).
Macaroni and Rockhopper penguins are mainly zooplankton feeders and account for ca $85 \%$ of total crustacean consumption in the archipelago (Table 3). They have similar diets and feeding habits, and it has been suggested that competition for food is minimised by a difference of $3 \mathrm{wk}$ in the onset of breeding (Brown 1987, Brown \& Klages 1987). Their foraging range seems to be limited to shelf and slope waters (Stahl et al. 1985, Brown \& Klages 1987), where crustacean migrators are sufficiently abundant to supply all predators.

However, on closer analysis, a significant segregation in the feeding ecology of Macaroni and Rockhopper penguins can be shown. Rockhoppers feed almost exclusively on pelagic crustaceans. Fish and squid form only $2 \%$ of their diet (Table 3 ). They are strictly shelf feeders, foraging from 4 to $150 \mathrm{~km}$ (mean $33 \mathrm{~km}$ ) from the islands during the day and spending the night ashore (Brown 1987, Adams 1990).

In contrast, mesopelagic fish and squid form ca $52 \%$ of the diet of Macaroni penguins (Table 3). They feed both on the shelf and in slope waters (Stahl et al. 1985), with a foraging range of 60 to $300 \mathrm{~km}$ (Brown 1987 , Croxall \& Lishman 1987). Foraging occurs throughout the $24 \mathrm{~h}$ day, using shallow dives at night and deeper dives in the day (Croxall et al.1988)

We suggest that ecological segregation of the 3 main species of land-based predators in the Prince Edward Archipelago is achieved through a gradient in diet and feeding habits. The 2 extremes are represented by the shelf-feeding Rockhopper penguins and the oceanic feeding King penguins, with essentially crustacean and mesopelagic fish diets, respectively. Macaroni penguins occupy a position intermediate between Rockhoppers and Kings. Their diet comprises significant proportions of both crustaceans and mesopelagic fish, and their feeding range extends from the shelf to the deep slope waters, partly overlapping with the range of the other 2 species. 
Acknowledgements. We thank A. Robertson, A. Hirst, A Kemp and $M$. van den Berg of the Sea Fisheries Research Institute (Cape Town) for the technological support and expertise they provided throughout the survey. We are also very grateful to the chief scientist, B. Allanson, the master of the SA 'Agulhas', H. Toxopeus, his officers and crew for their cooperation and help at sea. O. Gon of the J. L. B. Smith Institute of Ichthyology, Grahamstown, is thanked for the identification of the fish specimens. Funding from the Department of Environment Affairs through the South African Scientific Committee for Antarctic Research (SASCAR) is gratefully acknowledged.

\section{LITERATURE CITED}

Adams, N. J. (1987). Foraging range of King penguins (Aptenodytes patagonicus) during summer at Marion Island. J. Zool., Lond. 212: 475-482

Adams, N. J. (1990). Feeding biology and energetics of King (Aptenodytes patagonicus) and Gentoo (Pygoscelis papua) penguins at sub-Antarctic Marion Island. Ph.D. thesis. University of Cape Town, p. 246

Adams, N. J., Brown, C. R. (1989). Dietary differentiation and trophic relationships in the sub-Antarctic penguin community at Marion Island. Mar. Ecol. Prog. Ser. 57: 249-258

Adams. N. J., Klages. N. T. (1987). Seasonal variation in diet of the King penguin (Aptenodytes patagonicus) at subAntarctic Marion Island. J. Zool., Lond. 212: 313-334

Adams, N. J., Klages, N. T. (1989). Temporal variation in the diet of the Gentoo penguin Pygoscelis papua at subAntarctic Marion Island. Col. Waterbirds 12: 30-36

Adams, N. J., Brown, C. R., Nagy, K. A. (1986). Energy expenditure of free-ranging wandering albatrosses Diomedea exulans. Physiol. Zool. 59: 583-591

Beers, J. R. (1976). Determination of zooplankton biomass. In: Steedman, H. F. (ed.) Zooplankton fixation and preservation. UNESCO Press, Paris, p. 37-84

Blankley, W. O. (1982). Feeding ecology of three inshore fish species at Marion Island (Southern Ocean). S. Afr. J. Zool. 17: $164-170$

Brown, C. R. (1987). Traveling speed and foraging range of Macaroni and Rockhopper penguins at Marion Island. J. Field Ornithol. 58: 118-125

Brown, C. R. (1989). Energy requirements and food consumption of Eudyptes penguins at the Prince Edward Islands. Antarctic Sci. 1: 15-21.

Brown, C. R., Klages, N. T. (1987). Seasonal and annual variation in diets of Macaroni (Eudyptes chrysolophus chrysolophus) and Southern Rockhopper (E. chrysocome chrysocome) penguins at sub-Antarctic Marion Island. J. Zool., Lond. 212: 7-28

Brown, C. R., Klages, N. T., Adams, N. J. (1990). Short and medium-term variation in the diets of penguins at Marion Island. S. Afr. J. Antarct. Res. 20: 13-20

Condy, P. R. (1981). Annual food consumption and seasonal fluctuations in biomass of seals at Marion Island. Mammalia 45: 21-30

Cooper, J., Berruti, A. (1989). The conservation status of South Africa's continental and oceanic islands. In: Huntley, B. J. (ed.) Biotic diversity in southern Africa: concepts and conservation. Oxford University Press, Cape Town, p. $239-253$

Croxall, J. P. (1984). Seabirds. In: Laws, R. M. (ed.) Antarctic ecology, Vol. 2. Academic Press, London, p. 533-619

Croxall, J. P., Everson, I, Kooyman, G. L., Ricketts, C., Davis, R. W. (1985). Fur seal diving behavior in relation to vertical distribution of krill. J. Anim. Ecol. 54: 1-8

Croxall, J. P., Davis, R. W., O'Connell, M. J (1988). Diving patterns in relation to diet of Gentoo and Macaroni penguins at South Georgia. Condor 90: 157-167

Croxall, J. P., Lishman, G. S. (1987). The food and feeding ecology of penguins. In: Croxall, J. P. (ed.) Seabirds: feeding ecology and role in marine ecosystems. University Press, Cambridge, p. 101-133

De Witt, H. H., Heemstra, P. C., Gon, O. (1990). Nototheniidae. In: Gon, O., Heemstra, P. C. (eds.) Fishes of the Southern Ocean. J. L. B. Smith Institute of Ichthyology, Grahamstown, p. 279-331

Duhamel, G. Hureau, J. C. (1985). The role of zooplankton in the diets of certain sub-Antarctic marine fish. In: Siegfried, W. R., Condy, P. R., Laws, R. M. (eds.) Antarctic nutrient cycles and food webs. Springer, Berlin, p. 421-429

Eastman, J. T. (1985). The evolution of neutrally buoyant notothenioid fishes: their specializations and potential interactions in the Antarctic marine food web. In: Siegfried, W. R., Condy, P. R., Laws, R. M. (eds.) Antarctic nutrient cycles and food webs. Springer, Berlin, p. $430-436$

Eastman, J. T. (1990). The biology and physiological ecology of notothenioid fishes. In: Gon, O., Heemstra, P. C. (eds.) Fishes of the Southern Ocean. J. L. B. Smith Institute of Ichthyology, Grahamstown, p. 34-51

Espitalier-Noel, G., Adams, N.J., Klages, N.T (1988). Diet of the Imperial cormorant Phalacrocorax atriceps at subAntarctic Marion Island. Emu 88: 43-46

Falk-Petersen, S., Hopkins, C. C. E. (1981). Zooplankton sound scattering layers in North Norwegian fjords: interactions between fish and krill shoals in a winter situation in Ullsfjorden and Oksfjorden. Kieler Meeresforsch. (Sonderh.) 5: 191-201

Fraser, W. R., Pitman, R. L., Ainley, D. G. (1989). Seabird and Fur seal responses to vertically migrating winter krill swarms in Antarctica. Polar Biol. 10: 37-41

Genin, A., Haury, L. Greenblatt, P. (1988). Interactions of migrating zooplankton with shallow topography: predation by rockfishes and intensification of patchiness. Deep Sea Res. 35: 151-175

Gon, O., Klages, N. T. (1988). The marine fish fauna of the sub-Antarctic Prince Edward Islands. S. Afr. J. Antarct. Res. 18: 32-54

Greenlaw, C. F., Pearcy, W. G. (1985). Acoustical patchiness of mesopelagic micronekton. J. mar. Res. 43: 163-178

Imber, M. J. (1973). The food of Grey-\{aced petrels (Pterodroma macroptera gouldii (Hutton)), with special reference to diurnal vertical migration of their prey. J. Anim. Ecol. 42: 645-662

Isaacs, J. D., Schwartzlose, R. A. (1965). Migrant sound scatterers: interaction with the seafloor. Science 150: $1810-1813$

Kooyman, G. L., Davis, R. W., Croxall, J. P., Costa, D. P. (1982). Diving depth and energy requirements of king penguins Science 217: 726-727

Kott, P. (1953). Modified whirling apparatus for subsampling of plankton. Aust. J. Freshwat. Res. 4: 387-393

Orr, M. H. (1981). Remote acoustic detection of zooplankton response to fluid processes, oceanographic instrumentation and predators. Can. J. Fish. Aquat. Sci. 38: 1096-1105

Perissinotto, R. (1989). The structure and diurnal variations of the zooplankton of the Prince Edward Islands: implications for the biomass build-up of higher trophic levels. Polar Biol. 9: 505-510

Perissinotto, R. (1992). Mesozooplankton size-selectivity and grazing impact on the phytoplankton community of the 
Prince Edward Archipelago (Southern Ocean). Mar. Ecol. Prog. Ser. 79: 243-258

Perissinotto, R., Boden, B. P. (1989). Zooplankton-phytoplankton relationships at the Prince Edward Islands during April/May 1985 and 1986. S. Afr. J. Antarct. Res. 19:26-30

Perissinotto, R., McQuaid, C. D. (1990). Role of the subAntarctic shrimp Nauticaris marionis in coupling benthic and pelagic food-webs. Mar. Ecol. Prog. Ser. 64: 81-87

Peryera, W. T., Pearcy, W. G., Carvey, F. E. Jr (1969), Sebastodes flavidus, a shelf rockfish feeding on mesopelagic fauna, with consideration of the ecological implications. J. Fish. Res. Bd Can. 26: 2211-2215

Robertson, A. A., Alexander, D. G. W., Miller, D. G. M. (1981). Modified collapsible opening and closing midwater trawls (RMT-8 and RMT-2). Fish. Bull. S. Afr. 14: 103-113

Siegfried, W. R. (1985). Oceanic birds of the Antarctic. In Bonner, W. N., Walton, D. W. H. (eds.) Key environments: Antarctica. Pergamon, Oxford, p. 242-265

Smith, V. R. (1987). The environment and biota of Marion

This article was submitted to the editor
Island. S. Afr. J. Sci. 83: 211-220

Stahl, J. C., Jouventin, P., Mougin, J. L., Roux, J. P., Weimerskirch, H. (1985). The foraging zones of seabirds in the Crozet Islands sector of the Southern Ocean. In: Siegfried, W. R., Condy, P, R., Laws, R. M. (eds.) Antarctic nutrient cycles and food webs. Springer, Berlin, p. 478-486

Targett, T. E. (1981). Trophic ecology and structure of coastal Antarctic fish communities. Mar. Ecol. Prog. Ser. 4: $243-263$

Wiebe, P. H., Boyd, S., Cox, J. L. (1975). Relationships between zooplankton displacement volume, wet weight, dry weight and carbon. Fish. Bull. U.S. 73: 777-786

Williams, A. J., Siegfried, W. R., Burger, A. 1., Berruti, A. (1979). The Prince Edward Islands: a sanctuary for seabirds in the Southern Ocean. Biol. Conserv. 15: 59-71

Wilson, R. P., Wilson, M.-P. T. (1990). Feeding ecology of breeding Spheniscus penguins. In: Davis, L. S., Darby, J. T. (eds.) Penguin biology. Academic Press, San Diego, p. 181-206

Manuscript first received: June 5, 1991

Revised version accepted: January 16, 1992 